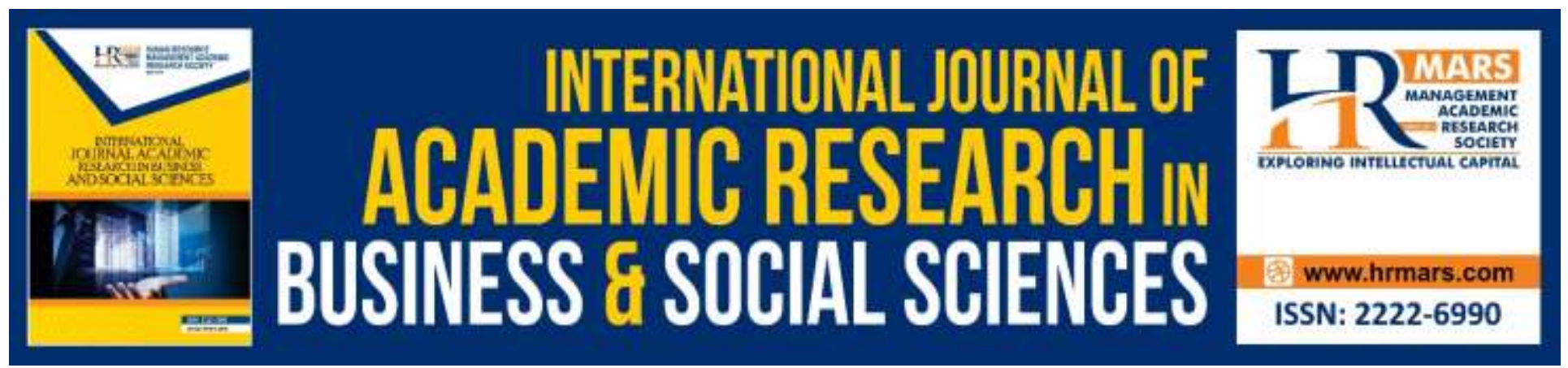

\title{
Role of Cloud Computing in Service Quality, Information Quality \& Low Costs: An Empirical Study on Jordanian Customs
}

Khaled Alzoubi, Nader Mohammad Aljawarneh, Yousef Alsafadi, Ahmad Tawfig Al-Radaideh \& Shadi Altahat

To Link this Article: http://dx.doi.org/10.6007/IJARBSS/v10-i6/7330

DOI:10.6007/IJARBSS/v10-i6/7330

Received: 24 March 2020, Revised: 19 May 2020, Accepted: 10 June 2020

Published Online: 21 June 2020

In-Text Citation: (Alzoubi et al., 2020)

To Cite this Article: Alzoubi, K., Aljawarneh, N. M., Alsafadi, Y., Al-Radaideh, A. T., \& Altahat, S. (2020). Role of Cloud Computing in Service Quality, Information Quality \& Low Costs: An Empirical Study on Jordanian Customs. International Journal of Academic Research in Business and Social Sciences, 10(6), 522-532.

Copyright: (C) 2020 The Author(s)

Published by Human Resource Management Academic Research Society (www.hrmars.com)

This article is published under the Creative Commons Attribution (CC BY 4.0) license. Anyone may reproduce, distribute, translate and create derivative works of this article (for both commercial and non-commercial purposes), subject to full attribution to the original publication and authors. The full terms of this license may be seen

at: $\underline{\text { http://creativecommons.org/licences/by/4.0/legalcode }}$

Vol. 10, No. 6, 2020, Pg. 522 - 532

http://hrmars.com/index.php/pages/detail/IJARBSS

JOURNAL HOMEPAGE

Full Terms \& Conditions of access and use can be found at http://hrmars.com/index.php/pages/detail/publication-ethics 


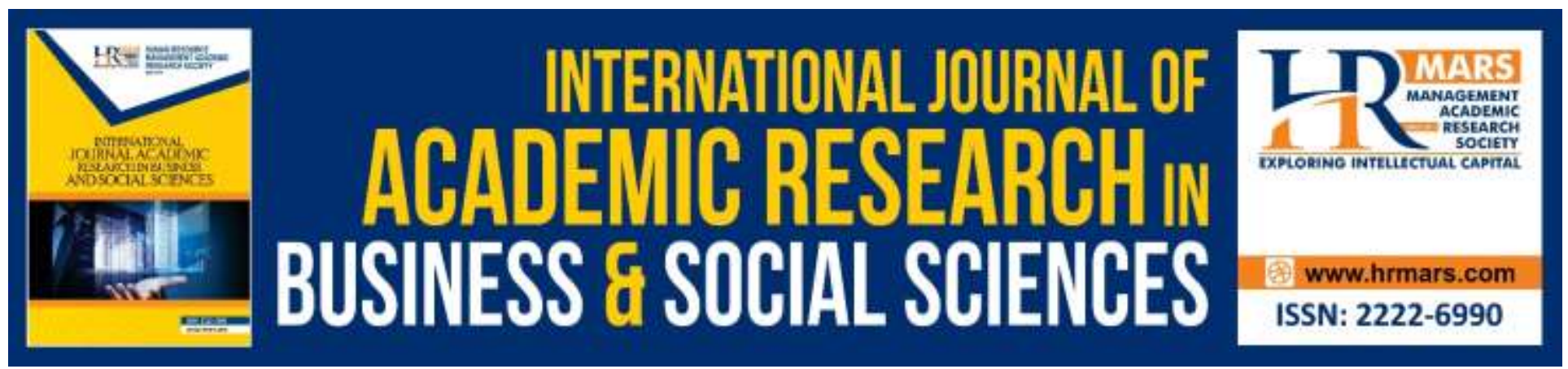

\title{
Role of Cloud Computing in Service Quality, Information Quality \& Low Costs: An Empirical Study on Jordanian Customs
}

\author{
Khaled Alzoubi, Nader Mohammad Aljawarneh, Yousef Alsafadi, \\ Ahmad Tawfig Al-Radaideh \& Shadi Altahat
}

Department of Business Administration, Business College, Jadara University, Irbid, Jordan

Email: n.jawarneh@jadara.edu.jo

\begin{abstract}
The study seeks to define the role of cloud computing in service quality, information quality and low costs. To achieve this research purpose, 207 employees were surveyed and there were 187 questionnaires valid for statistical analysis, adopting the descriptive approach. Questionnaires were used to measure the cloud computing impact on Jordanian customs. The study concluded that there was a high usage level of cloud computing and high level of application of service quality and information quality. In addition, there was a statistically significant correlation between cloud computing and service quality, information quality, and low costs. In light of the aforementioned results, Implementations for cloud computing and service quality, information quality, and low costs are discussed.
\end{abstract}

Keywords: Cloud Computing, Service Quality, Information Quality, Low Cost, Jordanian Customs.

\section{Introduction}

Cloud computing is a developing computing worldview that vowed to give chances to conveying an assortment of PC applications in a manner that has not been experienced previously (Sultan, 2009). With cloud computing, organizations and clients can approach applications everywhere throughout the world through any internet browser. We can envision a cloud computing framework as a virtualized PC framework that contains all products and applications required for organizations. According to Wade and Hulland, (2004) cloud computing provides organizations with a general sense diverse model of activity in which the specialist organizations are liable for hard parts in utilizing programming: establishment, update, upkeep, reinforcements, failover capacities, and security. Thus, the customers of cloud computing administrations will see the expanded unwavering quality and cost reductions because of economies of scale (Educause, 2009). They don't have to put resources into their own servers or utilize staff to deal with them. Rather, they simply need to pay for the administrations on request. These points of interest are significant for organizations, but they become even more urgent for independent companies that have restricted assets. According to 
Santhanam, and Hartono, (2003) utilizing cloud computing in administrations will spare them a great deal of time. Banks that utilize cloud computing will get similar advantages, for example, cost and efficiency, dependability of the administrations, responsive conveyance, so there isn't generally any leeway in utilizing cloud computing except if you can utilize it carefully to make your business distinguishable from contenders who sell similar items/administrations. As it were, an everincreasing number of independent ventures will utilize cloud computing on the off chance that it will empower them to improve their circumstances (Rokaya\& Al-Ghazzawi, 2018). This issue has not gotten satisfactory consideration both from the scholastic and pragmatic world. In this exploration, we will utilize the asset-based view hypothesis to build up an examination model for cloud computing and upper hands for private ventures (Al-Bdareen \& Khasawneh, 2019). The provider's satisfaction consists of boosting the advantage and use, while the buyer's satisfaction is reducing the cost that is going to be paid (Chan, et al 2007; Al-Badarin \& Al-Azzeam, 2017).

Bharadwaj (2000) says that, be that as it may, however, cloud computing has huge points of interest; there are difficulties in the zone of Quality of Service (QoS). According to Quittner, (2009) QoS indicates the degrees of execution, unwavering quality, and accessibility offered by an application and by the stage or foundation that has it. Any violation of service level agreement (SLA) involves a misfortune for both cloud suppliers and cloud clients. Over arrangement is regularly received by suppliers as a methodology to fulfill the SLA, yet it neglects to streamline asset use, particularly for private clouds. Chan, et al (2007) states that because of complexities that have influenced QoS affirmation, numerous specialists have been provoked to investigate mechanized QoS, and the board procedures that can handle the difficulties experienced by the clients and the cloud service suppliers. In this paper, we studied related productions from 2009 to 2015 to learn if the current procedures and executions have had the option to determine the issues of the nature of service in cloud computing. (Celuch, Murphy, and Callaway 2007)

According to Algrari, (2017) there are many challenges identified with the banking sector in Jordan. From the above-portrayed strategy, we can without a doubt see how a ton of room would be required to keep those records, likewise that it is so risky to shield those reports from a failure. Managing and keeping track of customers and business records is trying enough without including the constant endeavor of managing the report upkeep procedures express to each file type (Al-bdareen, 2020). Mani, et al. (2010) in addition, the cost of standard banking is high, so it's unrealistic for banks to open an unreasonable number of premises for prolonged periods of time. Mani, et al. (2010) expressed dissatisfaction in achieving these targets, which drove the banks to loss of congruity in customers. Cloud computing presents customers with an important advantage in that it eliminates as a concern the installation, maintenance and processing infrastructure for management. One begins to deal with a vision of computing resources, be they infrastructure, services or development platforms; as with the simple access to the Internet - it hires, binds, it is available and someone (the supplier) is responsible for ensuring the quality of service. Cloud computing enables organizations to focus their attention on their business, and provides them with a scalability scenario, both in terms of services and infrastructure, which become "unlimited". The cost, whose detailed analysis will not be the target of this paper, is presented as globally advantageous. (Cunha et al 2017). 
INTERNATIONAL JOURNAL OF ACADEMIC RESEARCH IN BUSINESS AND SOCIAL SCIENCES

Vol. 10, No. 6, June, 2020, E-ISSN: 2222-6990 @ 2020 HRMARS

\section{Literature Review}

\section{Cloud Computing's role in Service Quality, Information quality, and Low Costs}

Cloud computing today, is one of the leading technologies as it provides better prospects for future organizations (Gartner, 2011). Cloud computing is a moderately ongoing term despite the fact that it was based upon some current ideas. There are various meanings of cloud computing and we will survey them to reach a typical definition. As indicated by Gartner(2011), Cloud computing today is one of the main advances as it is by all accounts desired by future associations. Cloud Computing is a financially savvy answer for diminishing the necessities of associations and get together with business points, because of its adaptable, practical, and stable stage for conveying IT services to associations by means of the web (Hashizume et al., 2013; Obeidat, 2019).

The asset-based view hypothesis has been utilized widely in key administration inquiries and has been seen as a helpful strategy to assess the key estimation of a company's assets. At that point, it has been generally acknowledged and applied in IS inquire about. Utilizing the asset-based view hypothesis, IS analysts have had the option to assess the key estimation of IS assets, separate among different kinds of IS, and study their effects on execution (Santhanam\& Hartono, 2003). It was likewise demonstrated that unlike some assets, for example, brand value or budgetary resources, IS assets once in a while contribute an immediate impact to the continued upper hand. In this exploration, we will utilize and adjust the after effects of some IS studies to build up an examination model for cloud computing. Despite the fact that cloud computing gives various advantages to organizations, (Ravichandran and Lertwongsatien, 2002).

Quality of service means the level of execution, dependability, accessibility offered by an application, and by the stage or framework that has it. According to Chan, et al (2007), quality of service is basic to cloud clients, who anticipate that suppliers should convey the promoted qualities, and for cloud suppliers, who need to locate the correct tradeoff between levels and operational expense. Discovering the ideal tradeoff isn't a simple issue since it includes Service Level Agreements (SLAs) which determine quality of service targets and monetary punishments related to SLA infringement (Quittner, 2009). Service suppliers need to consent to SLA contracts which decide the income and punishments based on the accomplished exhibition level (Al-Qudah, et al., 2020). Service Level Agreements (SLA"s) are marked between the service supplier and the Customer where SLA infringement goes about as significant limitations.

According to Hoberg, et al (2012), computing insinuates the data development organization model, where hardware and programming organizations are passed on-solicitation to customers across (scattered) IT resources/sort out in a self-organization configuration, liberated from the contraption and zone. Resources given by the cloud can be intensely, adjusted mulling over dynamically perfect resource utilization. Yan, G. (2017, July). Cloud computing rose as the progression and mechanical progress of the framework and passed on computing, web organizations, the organization masterminded plan, utility computing, and virtualization (Obeidat \& Otibi, 2015). According to Hoberg, et al (2012), the guideline estimation of cloud computing for associations gets from offering resources in a traditionalist, flexible, and versatile way, which is sensible and speaking to IT customers and examiners. It will, in general, have fought for promising business points of interest of the cloud achieved increasing selective expectations. The utilization of Cloud Computing Services seems to offer significant cost advantages. Especially new businesses profit by these preferences since much of the time they don't work with an inner IT infrastructure. During the ongoing years, the meaning given by the National Institute of Standards and Technology (NIST) turned out to be exceptionally 
famous in research and in practice it was the same, since it gives a complete diagram: "Cloud computing is a model for empowering helpful, on-demand organize access to a common pool of configurable computing assets (for instance, systems, servers, stockpiling, applications, and services) that can be quickly provisioned and released with insignificant administration exertion or service supplier communication".

\section{Cloud Computing and Information Quality}

Cloud Computing is a model for empowering advantageous, on-demand organized access to a mutual pool of configurable computing assets (e.g., systems, servers, stockpiling, applications, and services) that can be quickly provisioned and released with negligible administration exertion or service supplier cooperation. Numerous different definitions are given. Cloud computing has got the chance to be used more to be a productive business. Cloud computing rose as the progression and mechanical progress of the framework and passed on computing, web organizations, the organization masterminded plan, utility computing, and virtualization. Step by step instructions to use cloud computing in making and continuing upper hand for organizations is pivotal for all organizations, particularly for private ventures who need to use every accessible asset seriously (Abualoush et al., 2018). An asset that can satisfy those necessities should be important, uncommon, matchless, and no substitutable (Barney, 1991).

H1: There is a positive relationship between cloud computing \& information quality.

\section{Cloud Computing and Service Quality}

Cloud Computing is a financially savvy answer for diminishing the necessities of associations and get together with business points, because of its adaptable, practical, and stable stage for conveying IT services to associations by means of the web (Hashizume et al., 2013). While it is confounded to an expansive range of services, cloud computing is typically a computing strategy that gives adjusted correspondence limits and alteration as assistance with associations by an outsider supplier that has an IT framework (Bisong and Rahman, 2011). Quality of Service (QoS) means the level of execution, dependability, accessibility offered by an application, and by the stage or framework that has it. Celuch, Murphy, and Callaway (2007) QoS are basic to cloud clients, who anticipate that suppliers should convey the promoted qualities, and for cloud suppliers, who need to locate the correct tradeoff between

H2: There is a positive relationship between cloud computing \& service quality.

\section{Cloud Computing and Low Cost}

In spite of the fact that it is fundamental for associations in potential advantages from associations' determined and working points of interest, it isn't as brisk as envisioned (Irtaimeh et al., 2016). The utilization of Cloud Computing Services seems to offer significant cost advantages. Especially new businesses profit by these preferences since much of the time they don't work an inner IT infrastructure. The pioneers of cloud computing are persistently executing new ideas to make pricing progressively appealing to clients which causes them to conquer their rivals. For instance, Microsoft Azure has acquainted the pricing every moment with coordinate the costs every hour is given by Amazon. Building a pricing plan requires associating costs to pricing for billable things and then consolidating these into various plans that are offered to cloud shoppers. Each billable thing can have 
INTERNATIONAL JOURNAL OF ACADEMIC RESEARCH IN BUSINESS AND SOCIAL SCIENCES

Vol. 10, No. 6, June, 2020, E-ISSN: 2222-6990 @ 2020 HRMARS

distinctive pricing alternatives that can be either fixed or variable pricing. Indeed, numerous suppliers offer distinctive pricing alternatives for the equivalent billable thing.

$H$ : There is a positive relationship between cloud computing \& low cost.

\section{Methodology}

The quantitative method was used to test the study hypotheses (al-Bourini et al., 2020). The study questionnaire was designed to collect data from the study sample and to determine their perceptions to know the quality of service, the quality of information, and the low cost in the Jordanian Customs administration. The questionnaire is divided into five sections. The first section dealt with demographic variables including gender, age, educational level, work experience and title. The second section dealt with the respondent's perception of cloud computing. As for the third section, it covered the level of service quality, quality of information and low cost, data was collected from all workers in the Jordanian Customs Department (the main administration) where the current study population consists of about 478 employees of all administrative practices. According to Sekaran 2016, the appropriate sample for this population consists of 208 respondents, who were randomized. As such, 208 questionnaires were distributed, and 187 analytic questionnaires were retrieved. The first table shows descriptive statistics of demographic variables. Where the data indicated that approximately $81.5 \%$ of the respondents are male, the proportion of the age group under 45 years is $73 \%$ of the sample and that $65 \%$ hold a Bachelor's degree. The table also shows, moreover, approximately 37 respondents with less than fifteen years of experience, the table shows that most of the respondents $87.3 \%$ the proportion is in the staff.

Table 1. Distribution of the sample population according to demographic variables

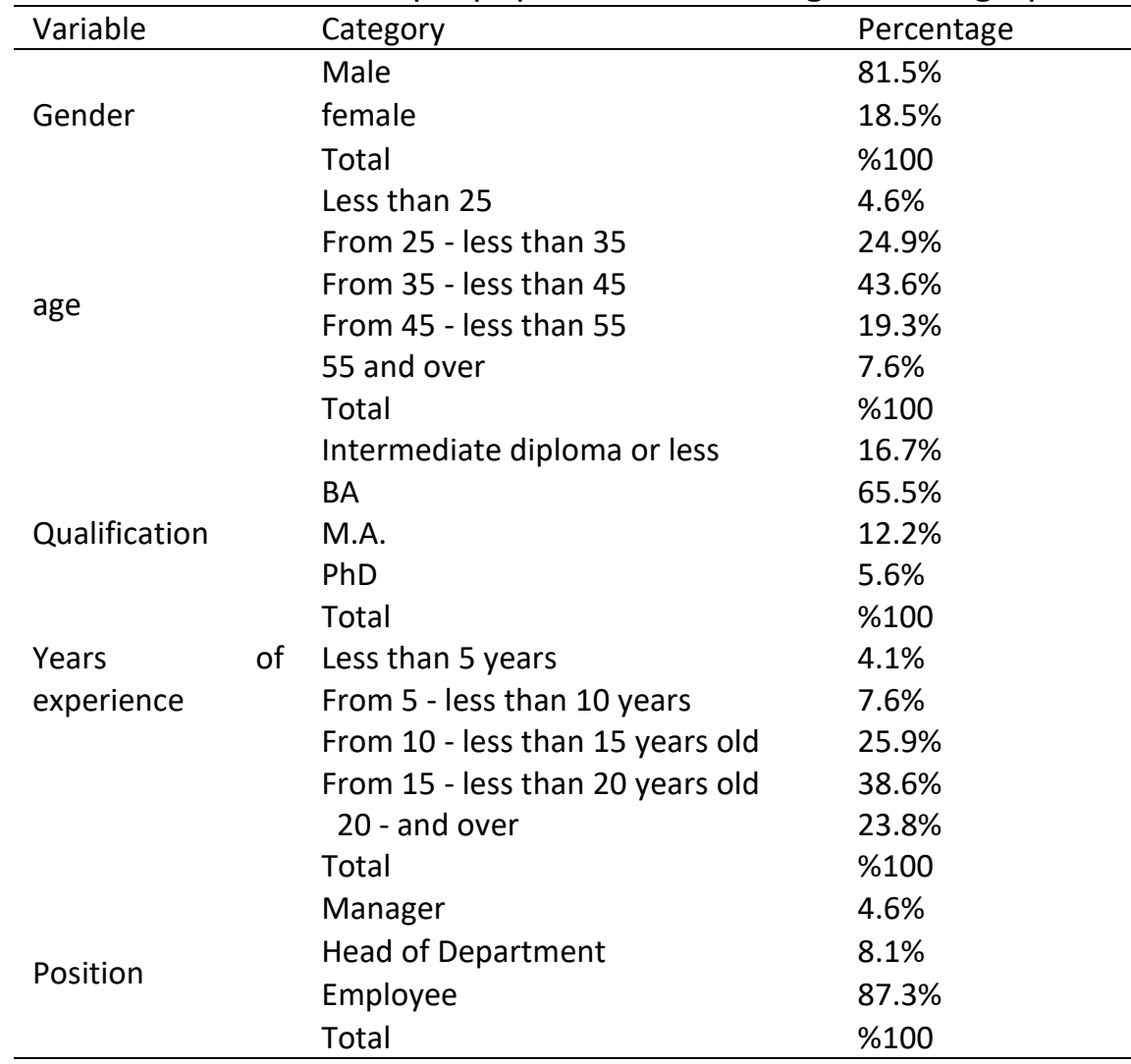


INTERNATIONAL JOURNAL OF ACADEMIC RESEARCH IN BUSINESS AND SOCIAL SCIENCES Vol. 10, No. 6, June, 2020, E-ISSN: 2222-6990 @ 2020 HRMARS

Table 2 presents the results of the analysis of the responses of the study sample members concerning the variables of the study model, using descriptive statistical methods of arithmetic averages, standard deviations, grades, and relative importance, as well as the high level of relative importance of the variables of Service Quality, Quality \& Low Cost, where the computational averages of the dependent variables ranged from 3.710 to 3.934 as shown by the table that the level of relative importance of the variables of the Independent Clouding Computing variable. At an average level of 3,152

Table 2: Analysis of study variables

\begin{tabular}{lllll}
\hline$\#$ & variable & Mean & SD & level \\
\hline 1 & Cloud Computing & 3.152 & 0.751 & Med \\
2 & Service Quality & 3.791 & 0.611 & High \\
3 & Information quality & 3.934 & 0.635 & High \\
4 & Low Cost & 3.710 & 0.500 & High \\
\hline
\end{tabular}

To ensure that the tool is stable, and internal consistency values were tested the results as shown in Table 3.

Table 3. Internal Consistency

\begin{tabular}{ll}
\hline Domains & $\begin{array}{l}\text { Internal } \\
\text { consistency }\end{array}$ \\
\hline Cloud Computing & 0.83 \\
Service Quality & 0.78 \\
Information quality & 0.74 \\
Low Cost & 0.75 \\
\hline
\end{tabular}

Table 3 shows that the values of the Cronbach Alpha showed an internal consistency coefficient for all dimensions of the resolution paragraphs ranged from $0.71-0.83$, where stability is considered weak if the coefficient values are less than 0.60 and assumed (Sekaran\&Bougie, 2015). The minimum stability factor is 0.70 , and stability is considered good whenever the values of the coefficient are 0.80 and above, so the values in the previous table are an indication of the stability of the study tool, the consistency of its paragraphs, reliability, and reliability for statistical analysis. 
INTERNATIONAL JOURNAL OF ACADEMIC RESEARCH IN BUSINESS AND SOCIAL SCIENCES

Vol. 10, No. 6, June, 2020, E-ISSN: 2222-6990 @ 2020 HRMARS

\section{Hypotheses Test}

$\mathrm{H}_{1}$ : Cloud Computing has positive impact on Service Quality

Table 4 Results of testing the effect of cloud computing on the service quality

\begin{tabular}{|c|c|c|c|c|c|c|c|c|c|}
\hline \multirow[b]{2}{*}{$\begin{array}{l}\text { dependent } \\
\text { variable }\end{array}$} & \multirow{2}{*}{$\mathbf{R}$} & \multirow{2}{*}{$\mathbf{R}^{2}$} & \multirow{2}{*}{$\mathbf{F}$} & \multirow{2}{*}{ Sig F* } & \multicolumn{5}{|l|}{ Coefficients } \\
\hline & & & & & $\begin{array}{l}\text { Independent } \\
\text { variable }\end{array}$ & $\beta$ & $\begin{array}{l}\text { Standard } \\
\text { error }\end{array}$ & $t$ & Sig* \\
\hline $\begin{array}{l}\text { Service } \\
\text { Quality }\end{array}$ & 0.427 & 0.173 & 49.461 & 0.000 & $\begin{array}{l}\text { Cloud } \\
\text { Computing }\end{array}$ & 0.489 & 0.077 & 7.884 & 0.000 \\
\hline
\end{tabular}

The results of the above table indicate that the effect of Cloud Computing on Service Quality is statistically significant, with the calculated $F$ value being 49.461 , and the Sig $F=0.000$ level below 0.05 , while the correlation coefficient was $R=0.427$, which refers to the positive relationship between the two variables, plus the value of the selection coefficient was $R 2=0.173$, indicating that $17.3 \%$ of the variation in Service Quality can be explained by the variation in Cloud Computing. The regression coefficient $=0.489 \beta$ refers to the total effect of cloud computing on Service Quality, which is a moral effect, where the value of $t$ was 7.884 .

$\mathrm{H}_{2}$ : Cloud Computing has positive impact on information quality

Table 5 Results of testing the effect of cloud computing on the Information quality of service

\begin{tabular}{|c|c|c|c|c|c|c|c|c|c|}
\hline \multirow[b]{2}{*}{$\begin{array}{l}\text { dependent } \\
\text { variable }\end{array}$} & \multirow{2}{*}{$\mathbf{R}$} & \multirow{2}{*}{$\mathbf{R}^{2}$} & \multirow{2}{*}{$\mathbf{F}$} & \multirow{2}{*}{ Sig $\mathrm{F}^{*}$} & \multicolumn{5}{|l|}{ Coefficients } \\
\hline & & & & & $\begin{array}{l}\text { Independent } \\
\text { variable }\end{array}$ & $\beta$ & $\begin{array}{l}\text { Standard } \\
\text { error }\end{array}$ & $\mathrm{t}$ & Sig* \\
\hline $\begin{array}{l}\text { Information } \\
\text { quality }\end{array}$ & 0.364 & 0.126 & 22.365 & 0.000 & Cloud & 0.298 & 0.058 & 5.437 & 0.000 \\
\hline
\end{tabular}

The results of the above table indicate that the effect of Cloud Computing on information quality is statistically significant, with the calculated $F$ value (22.365) and the indication level (Sig $F=0.000$ ) below 0.05 , while the correlation coefficient $(R)$ was $=0.364$ ) which refers to the positive relationship between the two variables, plus the value of the selection coefficient was ( $R 2=0.126$ ) and indicates that $12.6 \%$ of the variation in information quality can be explained by the variation in Cloud Computing. The regression coefficient $=0.298 \beta$ (refers to the total effect (Cloud Computing) on information quality is a moral effect, where the value of its t was (5.437) and the level of indication (Sig $=0.000)$

$\mathrm{H}_{3}$ : Cloud Computing has positive impact on Low Cost

Table 6 Results of testing the effect of cloud computing on the Low Cost

\begin{tabular}{|c|c|c|c|c|c|c|c|c|c|}
\hline \multirow[b]{2}{*}{$\begin{array}{l}\text { dependent } \\
\text { variable }\end{array}$} & \multirow{2}{*}{$\mathbf{R}$} & \multirow{2}{*}{$\mathbf{R}^{2}$} & \multirow{2}{*}{$\mathbf{F}$} & \multirow{2}{*}{$\begin{array}{l}\text { Sig } \\
\mathrm{F}^{*}\end{array}$} & \multicolumn{5}{|l|}{ Coefficients } \\
\hline & & & & & $\begin{array}{l}\text { Independent } \\
\text { variable }\end{array}$ & $\beta$ & $\begin{array}{l}\text { Standard } \\
\text { error }\end{array}$ & $\mathrm{t}$ & Sig* \\
\hline Low Cost & 0.519 & 0.274 & 89.342 & 0.000 & $\begin{array}{l}\text { Cloud } \\
\text { Computing }\end{array}$ & 0.537 & 0.057 & 8.519 & 0.000 \\
\hline
\end{tabular}


The results of the table above indicate that Cloud Computing has a statistically significant effect on low costs, with the calculated $F$ value being 89.342 , and the indication level (Sig $F=0.000$ ) which is less than 0.05 , while the correlation coefficient was $R=0.519$, which refers to the positive relationship between the two variables, plus the value of the selection coefficient was $R 2=0.274$, indicating that $27.4 \%$ of the variation in Low Cost can be explained by the variation in Cloud Computing. The regression coefficient $\beta=0.537$ refers to the total effect of cloud computing on Low Cost, which is a moral effect, where the value of its $t$ was $(8.519)$ and the level of indication $(\mathrm{Sig}=0.000)$,

\section{Results \& Recommendations}

The study results revealed the following: There was a significant impact of cloud computing on service quality. Another significant effect was observed regarding the impact of cloud computing on information quality. In terms of low costs, there was a significant effect of cloud computing in lowering costs. In light of the study results, the researchers recommend that it is beneficial for other enterprises working in the same field to employ the use of cloud computing in all departments with their applications. The management of Customs is also recommended to carry out training courses to enhance employees' performances. In addition, it is also important that the top management at Customs should perform all transactions of the organization on the basis of exactness and in a speedy process to ensure success of cloud computing in applications. Moreover, it is important that the management of Customs keeps alongside its various developments, the development of work procedures. Lastly, it is important to indicate the importance of further research and studies on cloud computing and institutional performance in other sectors.

\section{References}

Abualoush, S. H., Obeidat, A. M., Tarhini, A., Masa'deh, R. E., \& Al-Badi, A. (2018). The role of employees' empowerment as an intermediary variable between knowledge management and information systems on employees' performance. VINE Journal of Information and Knowledge Management Systems, 48(2), 217-237.

Akpan, H. A., \&Vadhanam, B. R. (2015). A survey on quality of service in cloud computing. International Journal of Computer Trends and Technology, 27(1), 58-63.

Al-Badarin, R. Q., \& Al-Azzeam, A. H. (2017). Job design and its impact on the job strain: Analysing the job as a moderating variable in the private hospitals in Irbid. International Journal of Humanities and Social Science, 7(3), 152-168.

Al-bdareen, R. (2020). The Impact of the Administrative Empowerment on the Employees Performance Management Process. International Journal of Asian Social Science, 10(4), 193206.

Al-Bdareen, R., \& Khasawneh, H. (2019). Human resources staffing process and its impact on job involvement: Irbid District Electricity Company as a case study. Problems and Perspectives in Management, 17(2), 254.

Al-Bourini, F. A., Aljawarneh, N. M., Bourini, I., Almaaitah, M. F., \&kaderAlomari, K. A. (2020). Directing Strategic Decision and Perceived Faculty Performance Using PLS Analysis and Monte Carlo Simulation in Jordanian Private Universities. Journal of Talent Development and Excellence, 12(3s), 2235-2252. 
INTERNATIONAL JOURNAL OF ACADEMIC RESEARCH IN BUSINESS AND SOCIAL SCIENCES Vol. 10, No. 6, June, 2020, E-ISSN: 2222-6990 @ 2020 HRMARS

Al-Jawarneh, N. M. S. (2016). Case Study: Business Management School at the Turkish Republic of North Cyprus and how Strategic Thinking and Planning Can Improve the Performance of the Organization to Maintain Stable between Competitors.

Aljawarneh, N. M. S., \&Atan, T. (2018). Linking Tolerance to Workplace Incivility, Service Innovative, Knowledge Hiding, and Job Search Behavior: The Mediating Role of Employee Cynicism. Negotiation and Conflict Management Research, 11(4), 298-320.

Aljawarneh, N., \& Al-Omari, Z. (2018). The Role of Enterprise Resource Planning Systems ERP in Improving Customer Relationship Management CRM: An Empirical Study of Safeway Company of Jordan. International Journal of Business and Management, 13(8), 86-100.

Alomari, K. (2010). Management bias as a cause of employee weak performance: Case Study at Jadara University. Management Science Letters, 10(8), 1729-1736.

Alomari, K. A. K. (2020). Linking between E-government and Money Laundering: The Mediating Role of Compliance Unit. INTERNATIONAL JOURNAL OF ACADEMIC RESEARCH IN BUSINESS AND SOCIAL SCIENCES, 10(2).

Alomari, Z. (2020). Does human capital moderate the relationship between strategic thinking and strategic human resource management? Management Science Letters, 10(3), 565-574.

Al-Omari, Z. S., Aljawarneh, N., Davut, S., \& Salah, A. (2018). The Impact of Marketing Mix Elements on Forming Mental Images about Islamic Banks in Jordan: An Empirical Study. OFFICIAL, 12, 54.

Al-Omari, Z., Alomari, K., \& Aljawarneh, N. (2020). The role of empowerment in improving internal process, customer satisfaction, learning and growth. Management Science Letters, 10(4), 841-848.

Alshare, F., Aljawarneh, N., Alomari, K., Alomari, Z., Albdareen, R., AAlwagfi, A., \&Alradaideh, A. (2020). Factors influencing cellular device purchase decisions in Jordan. Management Science Letters, 10(11), 2501-2506.

Alwagfi, A. A., Aljawarneh, N. M., \& Alomari, K. A. (2020). Work Ethics and Social Responsibility: Actual and Aspiration. Journal of Management Research, (12)1, 26-36.

Barney, J. B. (1991). Firm Resources and Sustained Competitive Advantage. Journal of Management, 17, (1), pp.99-120.

Buyya, R., Yeo, C. S., Venugopal, S., Broberg, J., Brandic, I. (2009). Cloud computing and emerging IT platforms: Vision, hype, and reality for delivering computing as the 5th utility, 25, pp. 599616.

Cunha, C. R., Morais, E. P., Sousa, J. P., \& Gomes, J. P. (2017). The role of cloud computing in the development of information systems for SMEs. Journal of Cloud Computing, 2017, 1-7.

Educause. (2009). 7 things you should know about cloud computing. Educause, August. URL: http://www.educause.edu

Forrester Research (2009). Is cloud computing ready for the enterprise? Forrester Research Report, May. URL: http://forrester.com

Hammond, S. (2008). Cloud computing: IT of the future or powderpuff? Enterprise Innovation, October-November, pp. 33-34. URL: http://www.enterpriseinnovation.com

Heinle, C., Strebel, J. (2010): laaS Adoption Determinants in Enterprises. Economics of Grids Clouds Systems and Services: 93-104.

Hilley, D. (2009): Cloud Computing: A Taxonomy of Platform and Infrastructure-level Offerings Cloud Computing. Georgia Institute of Technology, 
INTERNATIONAL JOURNAL OF ACADEMIC RESEARCH IN BUSINESS AND SOCIAL SCIENCES

Vol. 10, No. 6, June, 2020, E-ISSN: 2222-6990 @ 2020 HRMARS

Jayatilaka, B., Schwarz, A., Hirschheim, R. (2003): Determinants of ASP choice: an integrated perspective. European Journal of Information Systems 12(3):210- 224.

Kondo, D., Javadi, B., Malecot, P., Cappello, F., Anderson, D. P. (2009): Cost-Benefit Analysis of Cloud Computing versus Desktop Grids. Proceedings of the 2009 IEEE International Symposium on Parallel\&Distributed Processing.

Lenk, A., Klems, M., Nimis, J., Tai, S. (2009): What's Inside the Cloud? An Architectural Map of the Cloud Landscape. Proceedings of the 2009 ICSE Workshop on Software Engineering Challenges of Cloud Computing.

Li, X., Li, Y., Liu, T., Qiu, J., Wang, F. (2009): The Method and Tool of Cost Analysis for Cloud Computing. 2009 IEEE International Conference on Cloud Computing: 93-100.

Obeidat, A. (2019). IT Adaption with Knowledge Conversion Process (SECI). Management Science Letters, 9(13), 2241-2252

Obeidat, A. M., \&Otibi, G. A. (2015). The impact of knowledge sharing tools on levels of organizational learning (Field Study on Jordanian Commercial Banks). Australian Journal of Basic and Applied Sciences, 9(5), 253-267.

Obeidat, A. M., Abualoush, S. H., Irtaimeh, H. J., Khaddam, A. A., \&Bataineh, K. A. (2018). The role of organisational culture in enhancing the human capital applied study on the social security corporation. International Journal of Learning and Intellectual Capital, 15(3), 258-276.

Rastogi, G., \& Sushil, R. (2015). Cloud computing implementation: key issues and solutions. In 2015 2nd International Conference on Computing for Sustainable Global Development (INDIACom) (pp. 320-324). IEEE.

Rokaya, A. L., \& Al-Ghazzawi, H. (2018). Diversity training and its impact on the employees' organizational commitment: job satisfaction as a moderating variable in the Classic Fashion Apparel Industry company. International Journal of Business and Management, 13(10).

Saffar, N., \& Obeidat, A. (2020). The effect of total quality management practices on employee performance: The moderating role of knowledge sharing. Management Science Letters, 10(1), 77-90.

Truong, D. (2010). How cloud computing enhances competitive advantages: A research model for small businesses. The Business Review, Cambridge, 15(1), 59-65.

Chan, Y. E., Huff, S. L., Barclay, D. W., and Copeland, D. G. (1997). "Business strategic orientation, information systems strategic orientation, and strategic alignment," Information systems research, $8(2), 125-150$. 